\title{
Probabilistic SMF Tsunami Hazard Assessment for the upper East Coast of the United States
}

\author{
S. MARETZKI, S. GRILLI, C. D. P. BAXTER \\ Departments of Ocean and Civil and Environmental Engineering, University of Rhode \\ Island, Narragansett, RI, USA
}

\begin{abstract}
The level of tsunami hazard to the east coast of the United States is not well understood. This information is critical for the population, emergency services, and industry of the region. Assessing this hazard is particularly difficult because of the lack of tsunamis in the historical record and the uncertainty regarding the return periods of large-scale events that have been proposed, such as a large transoceanic tsunami possibly caused by a collapse of the Cumbre Vieja volcano in the Canary Islands, or a large coseismic tsunami initiated in the Puerto Rican subduction zone. The most significant tsunami hazard in this region, however, may be due to local submarine mass failures (SMF), which could cause concentrated damage in coastal communities located near the failures. This paper presents results of a probabilistic analysis that estimates the hazard, expressed in terms of runup (at a given probability of occurrence), of SMF tsunamis triggered by earthquakes, on the upper northeast coast of the United States. A Monte Carlo approach is employed, in which distributions of relevant parameters (seismicity, sediment properties, type and location of slide, volume of slide, water depth, etc.) are used to perform large numbers of stochastic stability analyses of underwater slopes, based on standard geotechnical methods. When slope failure occurs, initial tsunami characteristic height and runup are estimated, based on earlier numerical work, for specified return periods of seismic events. The overall hazard associated with SMF tsunamis along the coast is found to be quite low at most locations as compared, e.g., to the typical 100 year hurricane storm surge in the region $(5 \mathrm{~m})$. Two sites, however, located off of Long Island, New York and Atlantic City, New Jersey, show an elevated risk of higher tsunami runup $(5.0-7.5 \mathrm{~m})$. These two sites should be the focus of more detailed studies.
\end{abstract}

Keywords: Submarine mass failures, tsunami triggering; probabilistic analysis; tsunami hazard; runup analysis.

\section{Introduction}

The level of hazard posed by tsunamis to the upper east coast of the United States is not well understood. This information is critical for the populations, emergency services, and industry of the region. Assessing this hazard is particularly difficult because of the lack of tsunami observations made in the historical records of the region and the uncertainty regarding the return periods of large-scale events that have been identified in the literature. Events that could cause a large transoceanic tsunami include a volcano collapse of the Cumbre Vieja volcano in the Canary Islands (Ward and Day, 2001; Elsworth and Day, 1999; Hildenbrand et al., 2003), or a large co-seismic tsunami triggered by a magnitude 9 earthquake, initiated in the Puerto Rican subduction zone (W. Banks, United States Geological Survey, Personal Communication, 2006). A significant tsunami hazard in the east coast region may also be due to submarine mass failures 
(SMF) that could be triggered on the continental slope by local earthquakes of moderate magnitude (moment magnitude $>6$ or so), and cause concentrated damage to coastal communities located near the failures. Landslide tsunamis can be triggered much closer to shore than co-seismic tsunamis, so despite their much lower energy release, the runup and flooding they induce may result in significant local destruction along small concentrated sections of the nearby coastline. Warning times for SMF tsunamis may only be minutes rather than hours, which may increase the human toll. One such case is the July 1998 tsunami in Papua New Guinea. The tsunami was generated by an underwater slump, triggered by a 7.1 magnitude earthquake, and caused up to $16 \mathrm{~m}$ runup on a nearby low lying barrier island, leading to 2,000 fatalities (e.g., Tappin et al., 2001, 2002, 2007).

For large but low probability single transoceanic events, once a tsunami source scenario has been identified and parameterized, based on ad hoc seismological/geological hypotheses, direct modeling with a long wave propagation model can be performed. Provided accurate ocean and coastal bottom bathymetry and topography are available, and a fine enough coastal grid is used in the model, estimates of runup distributions and flooding areas can be made. There are numerous examples of this approach in the literature, including for the catastrophic December 26, 2004 Indian Ocean tsunami (Grilli et al., 2007; Ioualalen et al., 2007). The same methodology has also been applied to known landslide tsunami case studies to provide a better understanding of the events (e.g., Watts et al., 2003; Day et al., 2005).

There is considerable geologic evidence of submarine mass failures along the northeast coast of the United States (e.g. Booth et al., 1985; Booth et al., 2002; Piper et al., 2003, and others). Because of this evidence, it may be assumed that potentially tsunamigenic SMFs can be triggered by seismic activity at thousands of sites on the continental shelf and slope, and appear in a variety of sizes and mechanisms. Hence, the first task is to identify and quantify these numerous SMF tsunami sources, and attach a probability to the coastal runup each of these could cause. Considering the many parameters, uncertainties, and sheer size of this investigation, in a first phase, we precluded direct modeling of each potential SMF tsunami event (both slope stability and tsunami generation/propagation/runup) and instead performed a probabilistic analysis aimed at estimating the coastal runup of seismically triggered SMF tsunamis, at given level of probability and return period. To this effect, a Monte Carlo Simulation (MCS) model was developed (e.g., Watts, 2004), in which distributions of relevant parameters affecting SMFs (seismicity, sediment properties, type and location of slide/slump, volume, water depth, etc.) are used to perform a large number of stochastic stability analyses of underwater slopes for many transects drawn across the continental shelf and slope in a selected section of the US East Coast. Slope stability analyses are performed in the MCS model using limit equilibrium methods (Maretzki, 2006). When slope failure is found to occur for a specified return period of seismic events (e.g., 100, 500 years), to which a local ground acceleration is associated, initial tsunami characteristic height and coastal runup are estimated based on earlier numerical work (Grilli and Watts, 2005; Watts et al., 2005). 
In this paper, we report on the development and validation of the MCS model, and present results for 100 year and 500 year SMF tsunami runup, at a 95\% confidence level.

\section{Development and validation of MCS model}

There are no major subduction zones in the upper North Atlantic Ocean, however, a $600 \mathrm{~km}$ long deep fault can be seen north of Puerto Rico (18 deg. N Lat. In Fig. 1a) in which a potentially large earthquake could occur. Along the upper east coast of the United States is a wide continental shelf that is supplied with sediment at several locations by large rivers (Fig. 1b). In this region, historical earthquakes have occurred mostly on land (Fig. 2), however, in 1929, the largest earthquake on record for Atlantic Canada, with a 7.1 magnitude, triggered a series of large underwater landslides on the slope of the Grand Banks that generated a tsunami that caused 27 fatalities and extensive damage in Newfoundland.

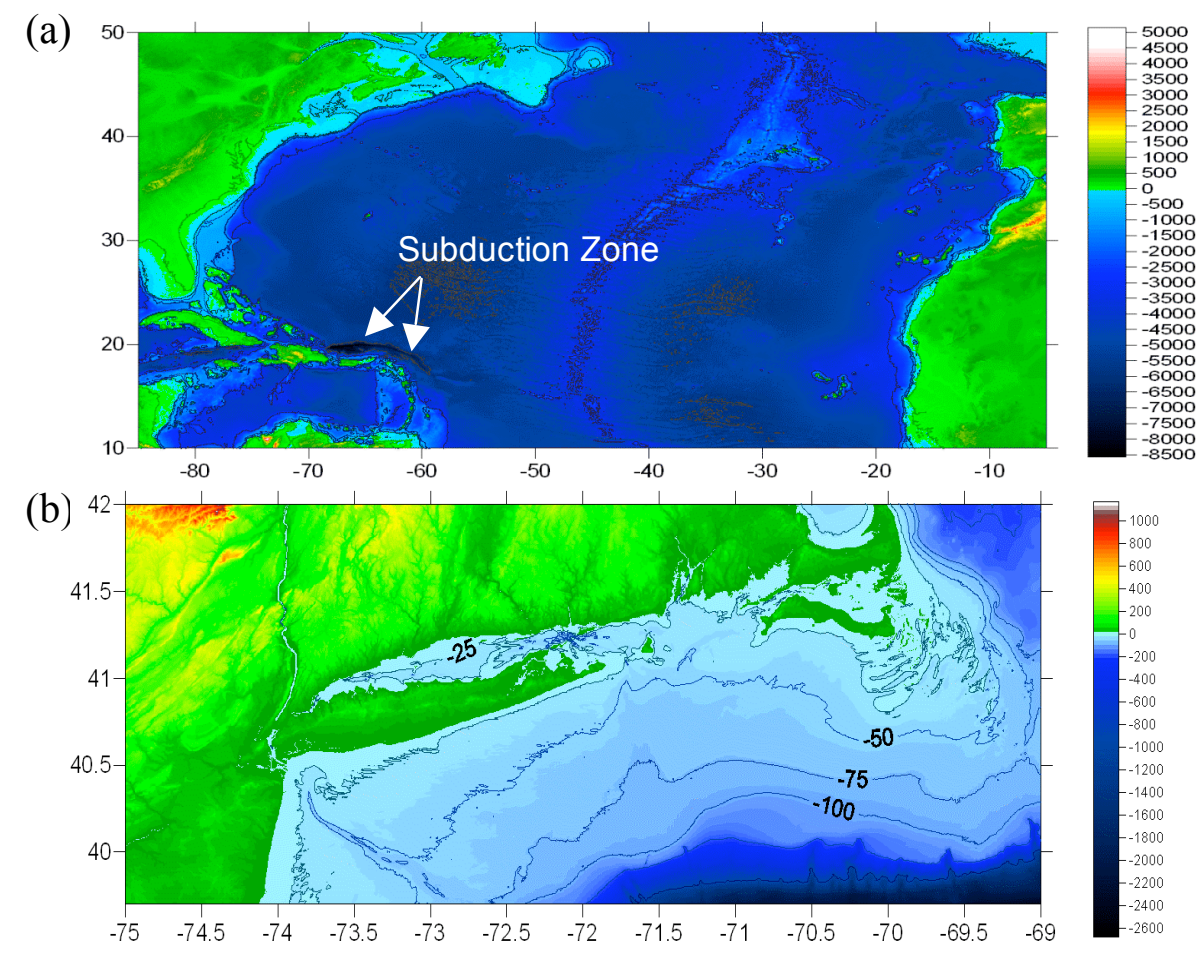

Figure 1: Bathymetry and topography in the North Atlantic Ocean (USGS data)

The MCS model was developed to investigate landslide tsunami risk in the region depicted in Fig. 1b, based on geographical, geological, sedimentary, and seismic data. For the latter, a historical (seismological) analysis of earthquakes (epicenter location, magnitude and extent, return period) was first performed for the region, based on publicly available United States Geological Survey (USGS) hazard maps (Fig. 2). Probability distributions were developed for peak horizontal accelerations in the bedrock as a function of the earthquake return period and the specified location on the continental shelf (Fig. 3). The choice of sediment properties provided the greatest uncertainty in the analysis due to the lack of information with depth. Information about surficial sediment 
types was obtained from the Continental Margin Mapping (CONMAP) database (Poppe et al., 2005). Based on these classifications, effective stress friction angles ( $\left.\phi^{\prime}\right)$ ranging from $28^{\circ}$ to $44^{\circ}$ were used for coarse-grained sediments and undrained shear strength ratios $\left(S_{\mathrm{u}} / \sigma_{\mathrm{v}}\right)$ ranging from 0.17 to 0.24 were used for fine-grained sediments in the MCS. The increase in bulk density with depth was assumed based on data from an Ocean Drilling Program Leg off the coast of New Jersey. Due to the high level of uncertainty in the types and thicknesses of sediment, no amplification or de-amplification of ground motions was considered. The sediment data, together with bathymetric and topographic data, was then used to create a number of GIS layers in ArcGIS 9 (Fig. 4). The bathymetric data was used to compute a series of transects (45) across the continental shelf and slope (Fig. 5), which, together with seismic (Fig. 3) and sediment (Fig. 4) data, were used as input for geotechnical models predicting slope stability in the MCS model.

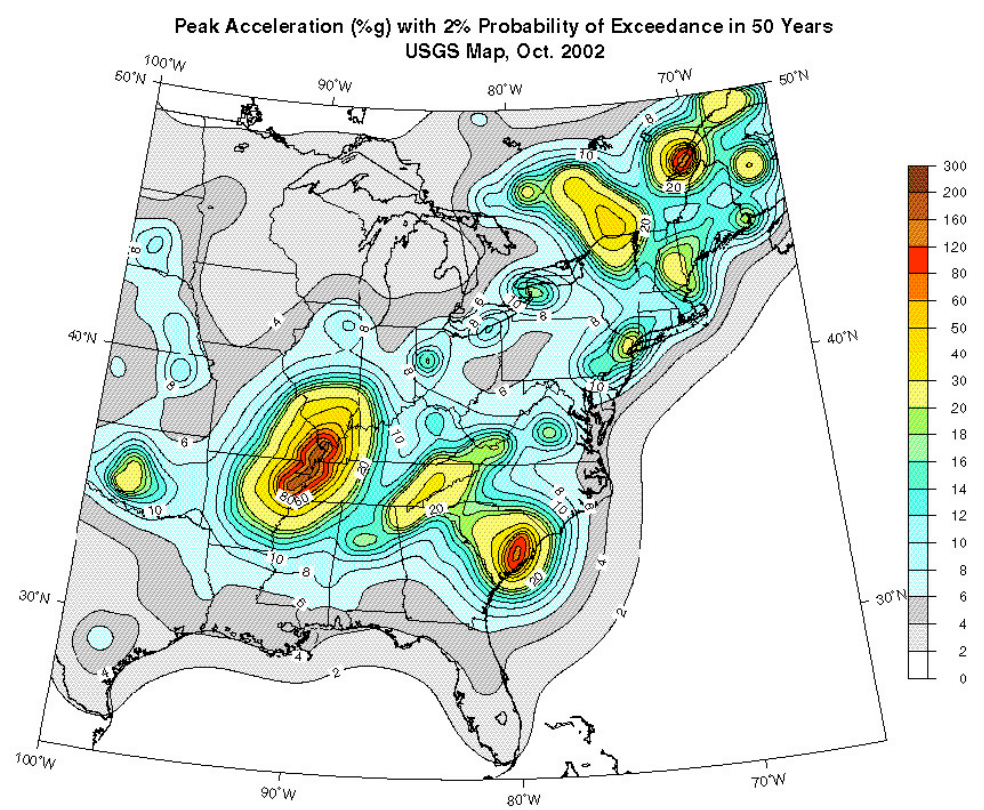

Figure 2: Seismicity of the Eastern continental United States (USGS, 2002)

Different limit equilibrium slope stability models were used depending on the type of sediment found along each transect. Failures in sandy sediments tend to be shallow and translational (i.e., in non-cohesive sediments), while clayey sediments tend to have deep rotational failures (i.e., slumps in cohesive sediments; Silva et al. 2004; Baxter et al. 2003; Soltau 2003). For selected cases the results of the MCS model have been verified using a commercial slope stability software package (Slope/W). [Details can be found in Maretzki (2006).]

In the MCS model, when slope failure is detected along one transect, given randomly selected slide/slump geometry, density and depth, an initial tsunami elevation is calculated, based on semi-empirical equations developed on the basis of numerical simulations and experimentally validated, for slides or slumps (Grilli and Watts, 2005; Watts et al., 2005; Enet and Grilli, 2007). The correspondence principle (which states that, all things considered, maximum runup caused by a SMF tsunami source on a nearby continental slope, is approximately equal to the initial tsunami characteristic amplitude; 
Watts et al., 2005) is then used to estimate runup, based on the maximum initial tsunami depression. Maximum runup for this particular event is assumed to occur in a primary direction of tsunami propagation, selected based on transect orientation (to which some randomness is associated), and runup is then modulated along-coast, assuming a normal variation and some angular spreading from the location of maximum runup. A large number of MCS simulations were performed for each selected return period and transect, and 800 points were used to calculate the runup probability distributions along the coast, based on MCS prediction for the triggered SMF events.

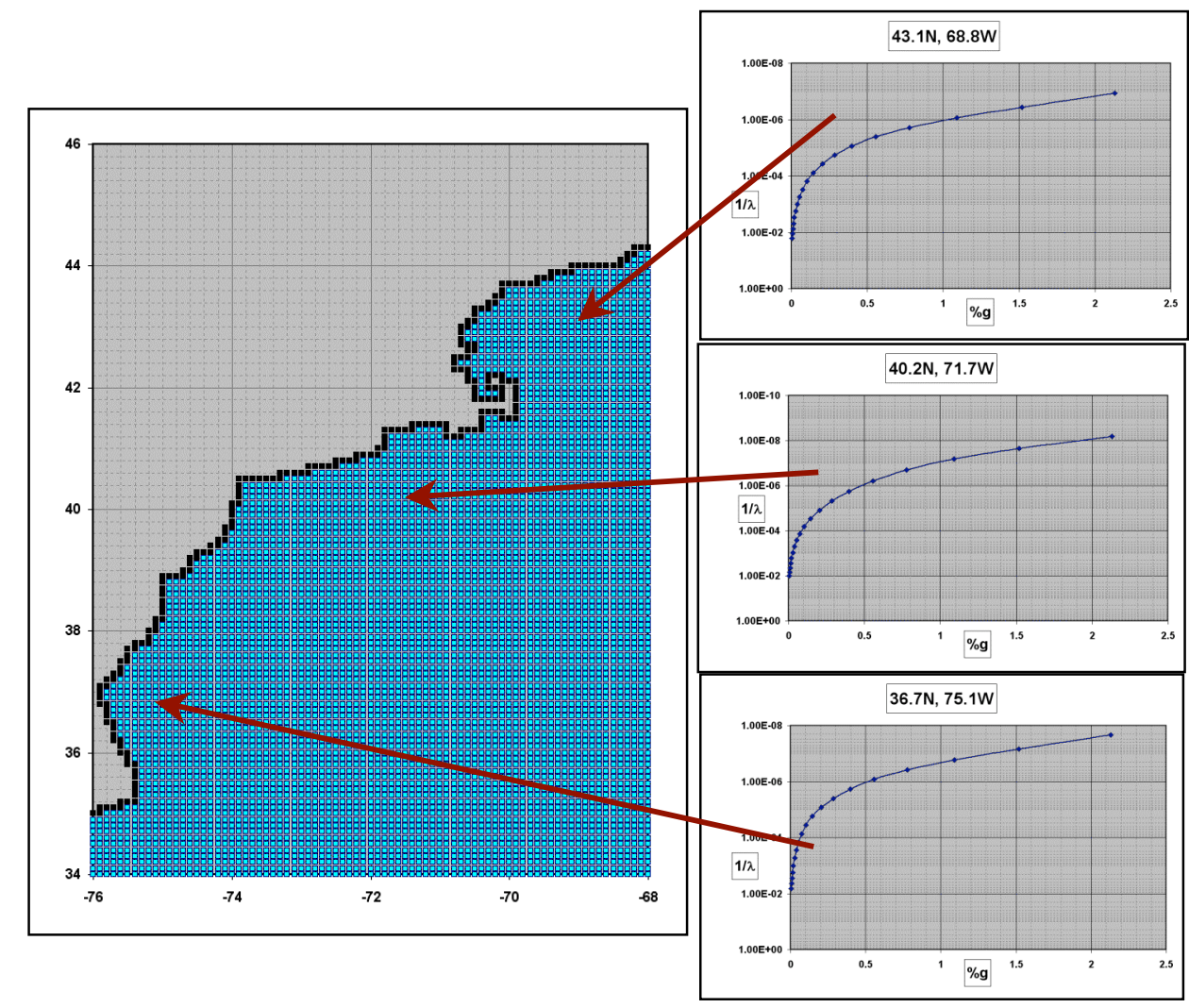

Figure 3: Typical annual probability of exceedance $\left(1 \times 10^{-2}\right.$ to $\left.1 \times 10^{-10}\right)$ for peak horizontal acceleration $(0$ to $2.5 \mathrm{~g}$ ) at various locations in the study area. This data is developed from the USGS hazard map shown in Fig. 2.

Numerous validations of the MCS model output were performed to verify that statistical results satisfied expected probability distributions for both governing and output parameters; these were performed up to very long return periods, such as 10,000 years, using at least 10,000 MCS runs for each year and transect. In particular, the dimensions and volumes of estimated failures matched approximately distributions presented by Booth et al. (2002). All of these validations successfully confirmed the relevance of our MCS results. [Details can be found in Maretzki (2006).] We then concentrated on producing both detailed and accurate (i.e. converged) results for two return periods of interest : 100 and 500 years, for which we used 50,000 MCS runs for each transect. Along-coast runup results were then statistically analyzed. 


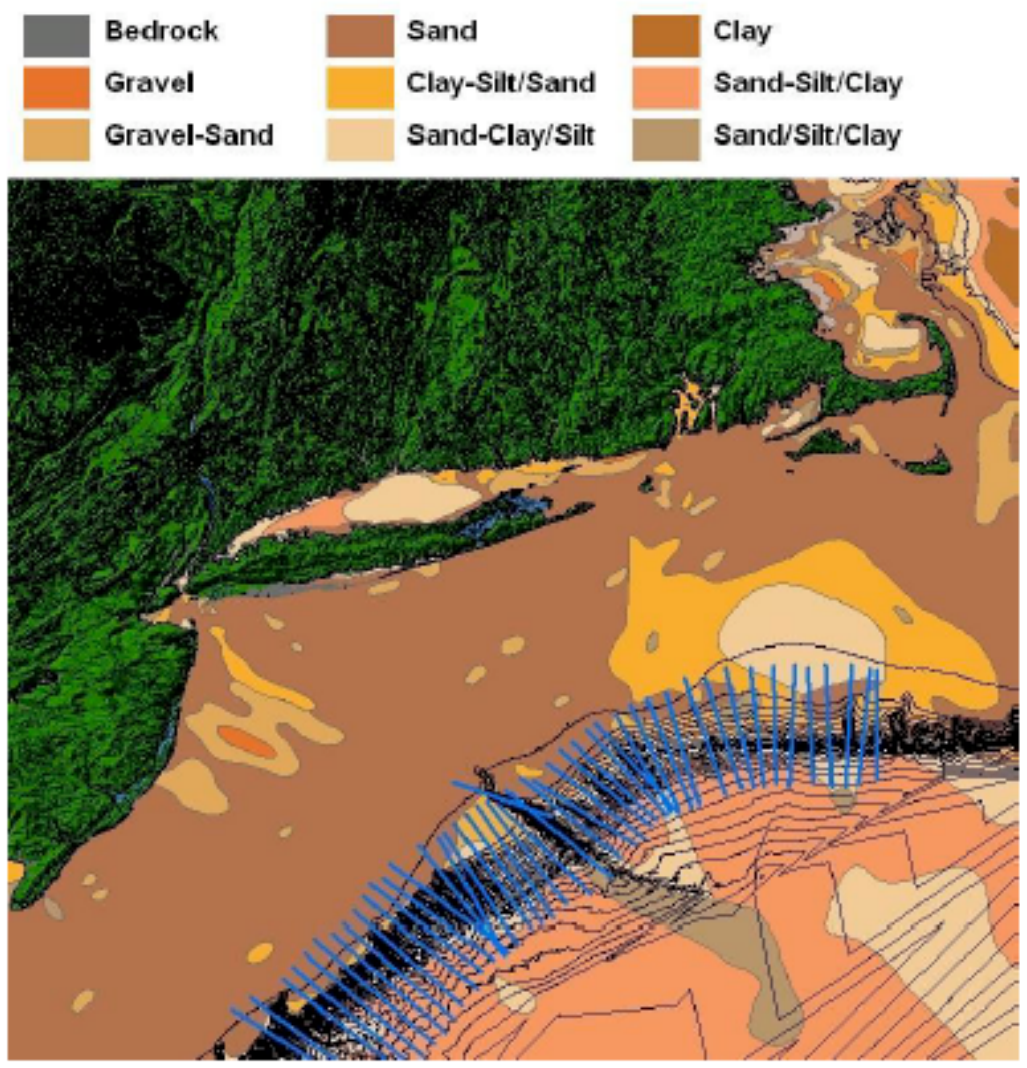

Figure 4: Color-coded ArcGIS sediment data and topography, and contoured bathymetry. The forty-five transects used in the slope stability analyses are also shown.

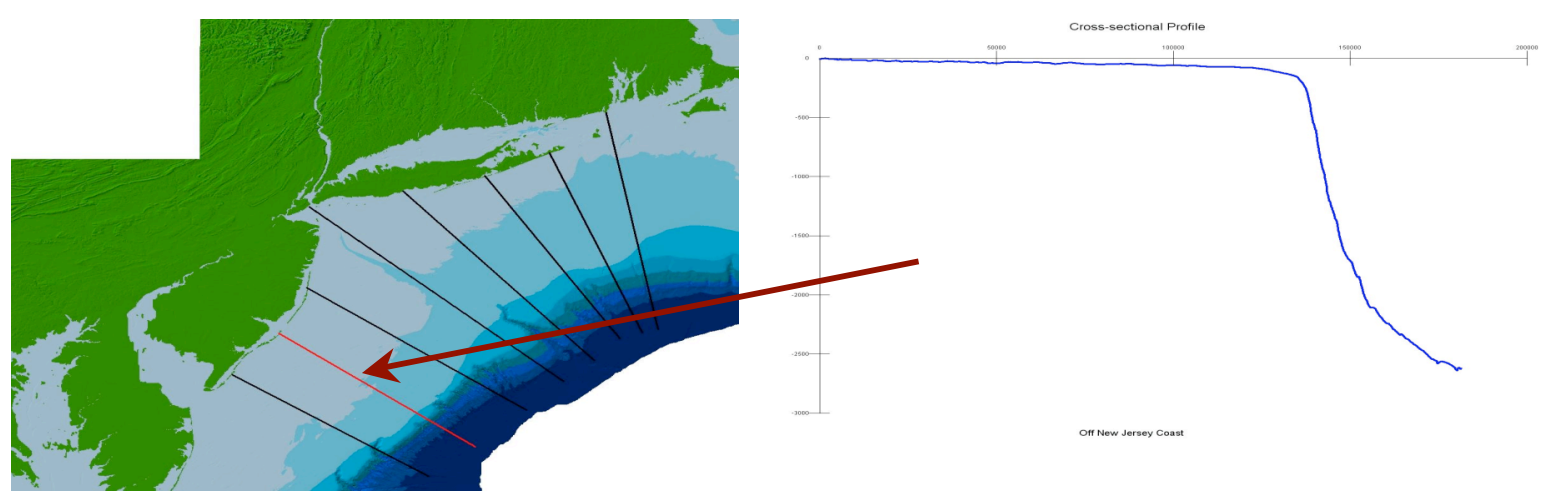

Figure 5: ArcGIS color coded bathymetry and one example of transect

\section{Results of MCS model}

Coastal runups predicted for a given seismic return period were found to satisfy a log-normal probability distribution. Based on these predictions, confidence limits (e.g., upper bound of $95 \%$ or $97.5 \%$ confidence intervals) could be calculated using standard Gauss (or Student $\mathrm{t}$ for less than 30 individual runup results) statistical distributions. Figure 6 shows results of MCSs, for 100 and 500 year return periods, of SMF tsunami runup, at 95\%, 97.5\% levels, along the selected section of US coastline. In Figure 6a, 
which shows results for the standard 95\% level used in probabilistic engineering design, the overall hazard associated with SMF tsunamis along the coast is found to be quite low at most locations, as compared to the typical 100 year hurricane storm surge in the region $(5 \mathrm{~m})$. Two sites, however, located near Long Island, New York (coastal points no. 500520) and Atlantic City, New Jersey (coastal points no. 660-760) show an elevated risk of higher tsunami runup in the range $5-7.5 \mathrm{~m}$. Figure $6 \mathrm{~b}$ further shows that these values would range between 5 and $11.8 \mathrm{~m}$, at a $97.5 \%$ confidence level, a level that could be selected, e.g., for designing more important structures (e.g., for energy production or homeland security).
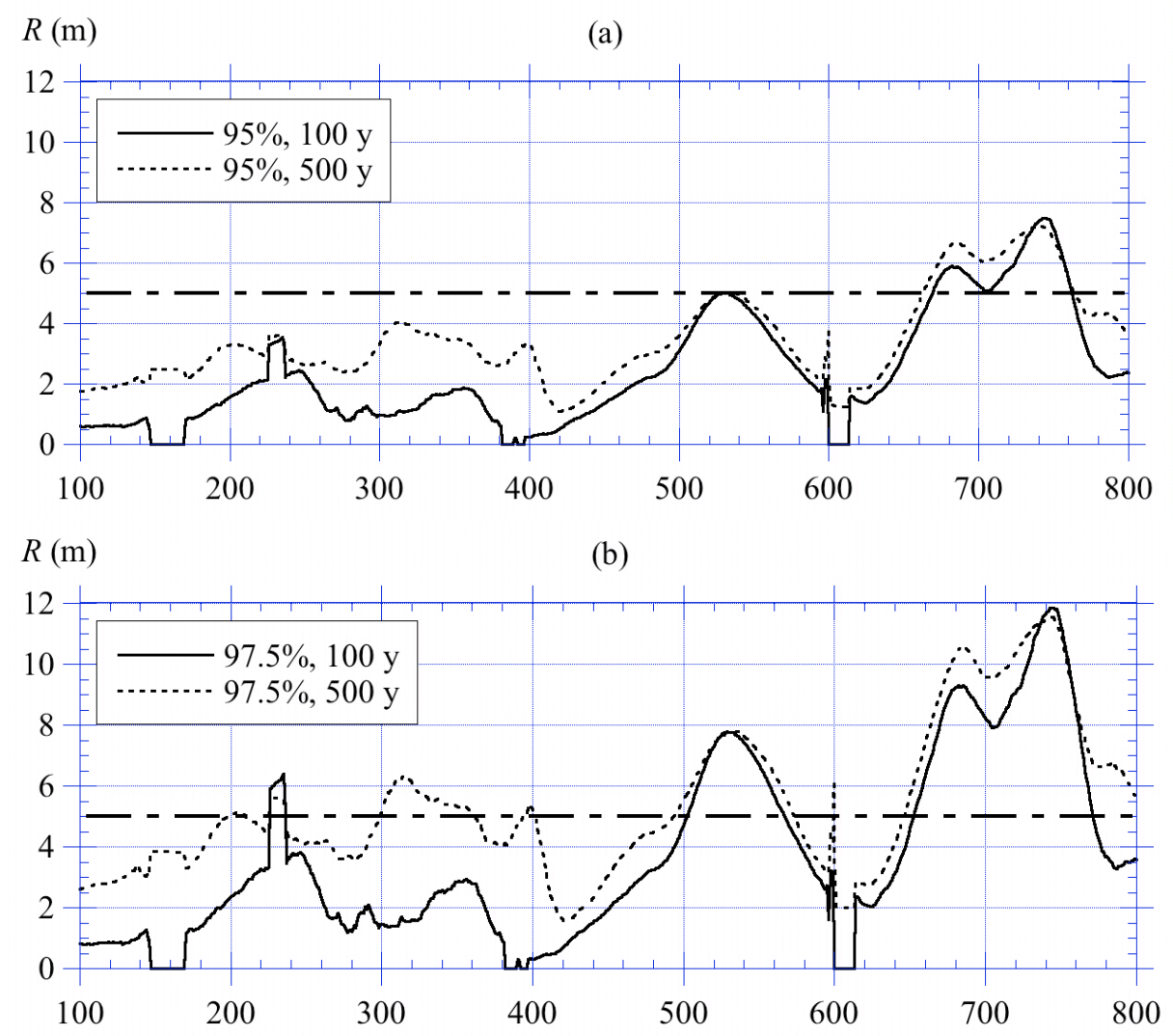

Figure 6 : MCS Runup at a: (a) 95\%; (b) 97.5\%, confidence levels (upper bounds), caused by SMF tsunamis, triggered by 100 or 500 year seismic events

( $\mathrm{x}$-axis is index of studied coastal points, numbered E-W, as detailed in Maretzki, 2006).

\section{Conclusions}

We developed a MCS model and applied it to assess SMF tsunami risk, in terms of runup, along the upper US East Coast. Considering the many simplifications and assumptions inherent to this analysis, it is understood that it is only aimed at identifying coastal locations with a higher probability for large runup, for which more detailed tsunami modeling studies should be performed in order to better assess tsunami hazard. 
We thus identified two sections of the US East coast with increased risk of tsunami runup, larger than the typical 100 year storm surge $(5 \mathrm{~m})$, at $95 \%$ and $97.5 \%$ confidence levels. These areas will be the focus, in future work, of more detailed studies, including direct modeling of SMF triggering, tsunami generation, and propagation/runup, over detailed coastal bathymetry and topography. Of critical importance will be reducing the uncertainty in the assumed geotechnical properties and stratigraphy.

Flooding area estimates could be inferred from runup distributions predicted along the coast, as a function of the coastal topography, but these will also be obtained in the more accurate direct simulations that will be performed in future work.

\section{Acknowledgements}

The authors gratefully acknowledge support for this work from a grant from FM Global, Inc. to the University of Rhode Island. The authors would also like to thank Dr. Homa Lee for his thoughtful review comments during the final preparation of this manuscript.

\section{References}

Baxter, C.D.P, King, J.W., Silva, A.J., and Bryant, W.R. (2003). "Investigation of the Age of Submarine Slope Failures in the Gulf of Mexico." Proc. Intl. Soc. of Offshore and Polar Engng. Conf., Honolulu.

J. S. Booth, R. C. Circe, and A. G. Dahl. (1985). "Geotechnical Characterization and Mass-Movement Potential of the United States North Atlantic Continental Slope and Rise," US Geological Survey, Tech. Rep., pp. 85-123.

J. S. Booth, D. W. O’Leary, P. Popenoe, and W. W. Danforth (2002). "U.S. Atlantic Continental Slope Landslides: Their Distribution, General Attributes, and Implications," U.S. Geological Survey Bulletin 2002, pp. 14-22.

Day, S. J., P. Watts, S. T. Grilli and Kirby, J.T. (2005). "Mechanical Models of the 1975 Kalapana, Hawaii Earthquake and Tsunami." Marine Geology, 215(1-2), 59-92.

Enet, F. and Grilli, S.T. (2007). "Experimental Study of Tsunami Generation by Three-dimensional Rigid Underwater Landslides.” J. Waterway Port Coastal and Ocean Engineering (in press).

Elsworth, D., and Day, S.J. (1999). "Flank collapse triggered by intrusion: the Canarian and Cape Verde Archipelagoes." J. Volcanology and Geothermal Res., 94, 323-340.

Grilli, S.T., Ioualalen, M, Asavanant, J., Shi, F., Kirby, J. and Watts, P. (2007.) "Source Constraints and Model Simulation of the December 26, 2004 Indian Ocean Tsunami." J. Waterway Port Coastal and Ocean Engineering (in press).

Grilli, S.T., and Watts, P. (2005). "Tsunami Generation by Submarine Mass Failure. I: Modeling, Experimental Validation, and Sensitivity Analyses.” J. Waterways, Ports, Coastal, and Ocean Engng., 131(6), pp 283-297.

Hildenbrand, A., Gillot, P.Y , Soler, V. and Lahitte, P. (2003). "Evidence for a persistent uplifting of La Palma (Canary Island), inferred from morphological and radiometric data." Earth and Planetary Science Letters, 210, 277-289.

Ioualalen, M. , Asavanant, J., Kaewbanjak, N., Grilli, S.T., Kirby, J.T. and Watts, P. (2007). "Modeling the 26th December 2004 Indian Ocean tsunami: Case study of impact in Thailand.” J. Geophys. Res. (in press).

Maretzki, S. (2006). "Numerical Simulation of Tsunami Hazard Maps for the US East Coast." Masters Thesis. Department of Ocean Engineering, University of Rhode Island, $187 \mathrm{pp}$.

Piper, D.J.W., Mosher, D.C., Gauley, B.-J., Jenner, K., and Campbell, D.C. (2003). "The Chronology and Recurrence of Submarine Mass Movements on the Continental Slope off Southeastern Canada," Submarine Mass Movements and their Consequences, Kluwer Academic Publishers, pp. 299-306.

Poppe, L. J., Williams, S. J., and Paskevich, V. F. (2005). "U.S. Geological Survey East-Coast Sediment Analysis: Procedures, Database, and GIS Data," US Geological Survey, Tech. Rep. 2005-1001, 2005. 
Silva, A.J., Baxter, C.D.P., LaRosa, P.T., and Bryant, W.R. (2004). "Investigation of Mass Wasting on the Continental Slope and Rise." Marine Geology, 203 (3-4), 355-366.

Soltau, B. (2003). "Evaluation of Paleoseismicity of Eastern North America from Subaqueous Slope Failures", Masters Thesis, Department of Civil and Environmental Engineering, University of Rhode Island, $152 \mathrm{pp}$.

Tappin, D. R., Watts, P., McMurtry, G. M., Lafoy, Y., and Matsumoto, T. (2001). "The Sissano, Papua New Guinea tsunami of July 1998 -- Offshore evidence on the source mechanism.” Marine Geology, 175, 1-23.

Tappin, D. R., Watts, P., McMurtry, G. M., Lafoy, Y., and Matsumoto, T. (2002). "Prediction of slump generated tsunamis: The July 17th 1998 Papua New Guinea event." Sci. Tsunami Hazards, 20(4), 222238.

Tappin, D.R., Watts, P., and Grilli, S.T. (2007). "The Papua New Guinea tsunami of 1998: anatomy of a catastrophic event." Natural Hazards and Earth System Sciences. (submitted).

United States Geological Survey (2002). "Conterminous States Probabilistic Maps \& Data," http://earthquake.usgs.gov/research/hazmaps/products_data/48_States/index.php (April 19, 2007).

Ward, S. N. and Day, S. (2001). "Cumbre Vieja Volcano-potential collapse and tsunami at La Palma, Canary Islands.” Geophys. Res. Lett., 28, 397-400.

Watts, P., Grilli, S.T., Kirby, J.T., Fryer, G.J. and D.R. Tappin, 2003. Landslide tsunami case studies using a Boussinesq model and a fully nonlinear tsunami generation model. Natural Hazards and Earth System Sciences, 3, 391-402.

Watts, P. (2004). "Probabilistic Predictions of Landslide Tsunamis off Southern California." Marine Geology, 203, 281-301.

Watts, P., Grilli, S.T., Tappin, D.R., and Fryer, G.J. (2005). "Tsunami Generation by Submarine Mass Failure. II: Predictive Equations and Case Studies." J. Waterways, Ports, Coastal, and Ocean Engng., 131(6), pp 298-310. 